\title{
KELAYAKAN ISI DAN BAHASA BUKU AJAR BAHASA INDONESIA SEKOLAH MENENGAH PERTAMA KELAS VIII KURIKULUM 2013 EDISI REVISI 2017 PENERBIT KEMENTERIAN PENDIDIKAN DAN KEBUDAYAAN Oleh
}

Muhammad Ridho Pradita (ridhopradita@gmail.com) Fitriani Lubis (rianiavandi@gmail.com) Universitas Negeri Medan

\begin{abstract}
ABSTRAK
Menurut Masnur Muslich (2010: 50) buku teks adalah buku yang berisi uraian bahan tentang mata pelajaran atau bidang studi tertentu, yang disusun secara sistematis dan telah diseleksi berdasarkan tujuan tertentu, orientasi pembelajaran, dan perkembangan siswa, untuk diasimilasi.dalam Peraturan Menteri Pendidikan Nasional Republik Indonesia (Permendiknas RI) No. 2 Tahun 2008 tentang buku Pasal 4 Ayat 1 disebutkan bahwa "Buku teks pada jenjang pendidikan dasar dan menengah dinilai kelayakan pakainya terlebih dahulu oleh Badan Standar Nasional Pendidikan (BSNP) sebelum digunakan oleh pendidik dan atau peserta didik sebagai sumber belajar." Penelitian ini bertujuan untuk mengetahui kelayakan isi dan kelayakan bahasa pada buku ajar Bahasa Indonesia SMP kelas VIII edisi revisi 2017 penerbit Kementerian Pendidikan dan Kebudayaan berdasarkan kriteria BSNP. Buku ajar Bahasa Indonesia SMP kelas VIII edisi revisi 2017 penerbit Kementerian Pendidikan dan Kebudayaan dari segi kelayakan isi sudah dikategorikan pada kategori sangat layak dengan persentase $84,54 \%$ dan segi kelayakan bahasa juga sudah dikategorikan pada kategori sangat layak dengan persentase $88,38 \%$. Hasil penelitian ini menunjukkan bahwa buku ajar Bahasa Indonesia SMP kelas VIII edisi revisi 2017 penerbit Kementerian Pendidikan dan Kebudayaansangat layak untuk digunakan untuk proses belajar mengajar dikelas.
\end{abstract}

Kata Kunci: Kelayakan Isi, Kelayakan Bahasa, Buku Ajar

\section{PENDAHULUAN}

Buku ajar atau buku teks merupakan salah satu instrumen dalam sebuah proses belajar mengajar. Buku ajar termasuk media yang penting guna tercapainya tujuan pembelajaran dalam kegiatan belajar mengajar di sekolah. Buku ajar dapat dijadikan sebagai pedoman dalam mengajarkan dan belajar sebuah disiplin keilmuan. Buku ajar juga membantu guru dalam menentukan materi yang akan disampaikan pada hari ini dan besok atau memfasilitasi siswa untuk bisa mempelajari materi yang 
telah disampaikan atau mempersiapkan apa yang menjadi materi pada esok hari. Oleh karena itu, buku ajar atau buku teks haruslah sempurna dari berbagai aspek dalam menyajikan materi-materi yang akan dijadikan sumber informasi bagi masyarakat, khususnya peserta didik dan guru.Buku ajar adalah buku pegangan untuk suatu matakuliah yang ditulis dan disusun oleh pakar bidang terkait dan memenuhi kaidah buku teks serta diterbitkan secara resmi dan disebarluaskan (Kepmendiknas, No 36 Tahun 2001).

Tujuan dari adanya buku ajar adalah untuk memudahkan pendidik dalam menyampaikan materi pembelajaran dan menyediakan materi pembelajaran yang baik dan menarik bagi peserta didik. Fungsi buku ajar dikatakan mampu untuk mengantarkan para pembaca dalam memahami isi buku adalah dengan adanya sarana-sarana khusus, seperti skema, gambar-gambar, ilustrasi, dan menyediakan metode untuk mudah memahami materi konsep, serta yang mampu menarik minat siswa untuk mempelajarinya.

Dunia pendidikan Indonesia sejak dulu sangat memperhatikan kelayakan buku ajar pada setiap disiplin ilmu. Terdapat berbagai aturan dan kriteria untuk menentukan kelayakan dalam penyusunan dan penyajian sebuah buku. Pemerintah sudah berupaya untuk menyediakan buku teks yang bermutu. Bentuk dari kegiatan ini adalah dibentuknya Badan Standar Nasional Pendidikan (BSNP) yang salah satu tugasnya adalah menilai kelayakan buku teks. Dalam Peraturan Menteri Pendidikan Nasional Republik Indonesia (Permendiknas RI) No. 2 Tahun 2008 tentang buku Pasal 4 Ayat 1 disebutkan bahwa "Buku teks pada jenjang pendidikan dasar dan menengah dinilai kelayakan pakainya terlebih dahulu oleh Badan Standar Nasional Pendidikan (BSNP) sebelum digunakan oleh pendidik dan atau peserta didik sebagai sumber belajar." Artinya, setiap satuan pendidikan wajib memiliki buku teks yang telah lolos dari penilaian BSNP. Badan Standar Nasional Pendidikan (BSNP) mempunyai kriteria tersendiri untuk buku teks yang digunakan dalam proses pembelajaran.

Dalam pengukuran kualitas buku ajar harus diperhatikan aspek-aspek penting, yaitu kesesuaian isi dengan kurikulum yang sedang berlaku, kesesuaian 
bahasa dengan perkembangan bahasa peserta didik, penyajian, dan kegrafikan. Apabila buku teks yang digunakan kesesuaian isi dengan kurikulumnya rendah maka kompetensi yang diharapkan akan sulit untuk tercapai. Hal ini dapat terjadi jika guru menganggap keseluruhan buku sudah baik dan menerima begitu saja tanpa menganalisis terlebih dahulu buku ajar yang akan digunakan.

Dalam pengukuran kualitas buku ajar harus diperhatikan aspek-aspek penting, yaitu kesesuaian isi dengan kurikulum yang sedang berlaku, kesesuaian bahasa dengan perkembangan bahasa peserta didik, penyajian, dan kegrafikan. Apabila buku teks yang digunakan kesesuaian isi dengan kurikulumnya rendah maka kompetensi yang diharapkan akan sulit untuk tercapai. Hal ini dapat terjadi jika guru menganggap keseluruhan buku sudah baik dan menerima begitu saja tanpa menganalisis terlebih dahulu buku ajar yang akan digunakan.

Sejak lama Indonesia memiliki lembaga yang khusus mengurus standar pendidikan yaitu Badan Standar Nasional Pendidikan (BSNP). Badan Standar Nasional Pendidikan (BSNP) merupakan lembaga yang berwenang menentukan kriteria dan seleksi terhadap kelayakan buku teks atau buku ajar pada jenjang pendidikan dasar dan menengah. Seperti yang disebutkan dalam Peraturan Menteri Pendidikan Nasional Republik Indonesia (Permendiknas RI) No. 2 Tahun 2008 tentang buku Pasal 4 Ayat 1 disebutkan bahwa "Buku teks pada jenjang pendidikan dasar dan menengah dinilai kelayakan pakainya terlebih dahulu oleh Badan Standar Nasional Pendidikan (BSNP) sebelum digunakan oleh pendidik dan atau peserta didik sebagai sumber belajar."

Menurut Masnur Muslich (2010:3) dalam hal kelayakan isi, ada tiga indikator yang harus diperhatikan, yaitu (1) kesesuaian uraian materi dengan standar kompetensi (SK) dan kompetensi dasar (KD) yang terdapat dalam kurikulum mata pelajaran yang bersangkutan; (2) keakuratan materi; dan (3) materi pendukung pembelajaran.

Bahasa yang digunakan dalam buku ajar atau buku teks harus diperhatikan dari berbagai kriteria kebahasaan. Melalui bahasa yang baik dan benar maka semua pesan dan informasi yang ingin disampaikan oleh penulis kepada pembaca dapat 
diterima dengan baik. Oleh karena itu, bahasa menjadi salah satu kriteria penilaian dalam sebuah buku ajar atau buku teks.

Agar terjadi komunikasi yang efektif melalui buku teks pelajaran, ada beberapa komponen yang perlu diperhatikan dalam menggunakan bahasa dalam ragam tulisan, yakni (1) kemampuan berbahasa siswa, (2) kaidah bahasa, (3) pilihan kata, (4) gaya bahasa, (5) keterbacaan (B. P. Sitepu, 2012: 108).

Namun, kenyataan yang ada dalam dunia pendidikan Indonesia saat ini, ternyata masih banyak buku ajar atau teks yang bermasalah mulai dari konten (muatan) materinya yang memuat konten berbau pornografi, sara, dan ideologi kewarganegaraan yang salah. Kurang mutakhirnya wacana, contoh, dan latihan yang terdapat pada sebuah buku. Banyak hal lain yang saat ini sangat disoroti dalam sebuah buku ajar atau teks yang digunakan dalam dunia pendidikan Indonesia.

Permasalahan-permasalahan tersebut dapat dilihat dalam berbagai kasus buku ajar seperti kasus yang beberapa tahun ini muncul di media salah satunya pada republika.co.id tahun 2015 yaitu buku pelajaran pendidikan agama Islam kelas XI, yang mengajarkan kekerasan. Materi buku yang mengajarkan Islam radikal itu berada pada halaman 78 di buku tersebut. Dalam halaman itu tertulis, para siswa diperbolehkan membunuh orang musyrik. Buku yang disusun tim MGPM itu juga sudah beredar ke sejumlah sekolah tingkat SMA yang ada di Kabupaten Jombang.

Kemudian kasus yang dimuat oleh Liputan6.com tahun 2015 yang membahas tentang Buku Olahraga dan Kesehatan untuk SD kelas 5 terbitan Pusat Perbukuan Kementerian Pendidikan Nasional 2010 yang ditulis oleh Dadan Heryana dan Giri Veriantika yang dinilai begitu vulgar. Seperti yang terdapat pada bab Menjaga Kebersihan Alat Reproduksi di halaman 57-62. Pada bagian rangkuman materi tersebut disebutkan ciri-ciri anak laki-laki yang tumbuh dewasa yang ditandai dengan mimpi basah, alat kelamin membesar, suara membesar, dan tubuh membesar. Selanjutnya, di pembahasan pelecehan seksual terdapat pula kalimat bagi perempuan yang hamil di luar nikah besar kemungkinan akan menggugurkan kandungannya. Beberapa orang tua siswa menganggap muatan materi dalam buku tersebut belum layak untuk siswa tingkat sekolah dasar. 
Kasus lainnya terkait kasus buku ajar Pendidikan Jasmani dan Olahraga SMA/MA/SMK kelas XI yang secara tidak langsung memperbolehkan pacaran. Sebagaimana yang dimuat dalam situs koran online republika.co.id tahun 2014 Pasalnya, dalam buku tersebut memuat materi memahami dampak seks bebas. Namun, yang mengundang protes adalah ilustrasi bukunya yang menampilkan seorang remaja pria berpeci dan remaja putri menggunakan jilbab di sebuah taman air terjun. Ilustrasi itu kemudian dilengkapi narasi bahwa gambar itu menunjukkan contoh pacaran sehat. Sejumlah kalangan pendidik pun bereaksi atas gambar itu dan menilai hal itu tidak sesuai syariat Islam.

Dari pemaparan di atas, peneliti tertarik untuk melakukan penelitian analisis kelayakan isi dan bahasa buku ajar atau teks. Buku ajar yang akan dijadikan bahan penelitian adalah buku ajar bahasa Indonesia kurikulum 2013 edisi revisi 2017 yang diterbitkan oleh Kementerian Pendidikan dan Kebudayaan Republik Indonesia.

Penelitian ini dinilai penting untuk dilaksanakan karena dengan adanya penelitian ini diharapkan dapat memberikan hasil terkait layak atau tidaknya buku ajar bahasa Indonesia kurikulum 2013 edisi revisi 2017 kelas VIII yang telah beredar di masyarakat. Selain itu, dari penelitian ini informasi yang disajikan dapat dijadikan refrensi bagi guru-guru bahasa Indonesia dalam memilih dan menilai buku ajar yang baik dan tepat untuk digunakan dalam kegiatan belajar mengajar.

\section{METODE PENELITIAN}

Penelitian yang akan dilakukan termasuk dalam jenis penelitian kualitatif. Penelitian ini dipakai untuk mendeskripsikan gejala-gejala yang diamati. Peneliti akan menghimpun, mengidentifikasi, menganalisis, dan mengadakan sintesis data dari buku ajar Bahasa Indonesia SMP kelas VIII Kurikulum 2013 revisi 2017 yang

diterbitkan oleh Kementerian Pendidikan dan Budaya. Metode dokumentasi yaitu mencari data mengenai hal-hal atau variabel yang berupa catatan, transkip, buku, surat kabar, majalah, prasasti, notulen rapat, lengger, agenda, dan sebagainya (Arikunto, 2010:274). 
Analisis data penelitian ini mengacu pada model analisis mengalir, sepertiyang dikemukakan oleh Miles dan Huberman, yaitu reduksi data, penyajian data,dan penarikan simpulan. Dengan model mengalir ini, penulis akan melakukananalisis data secara kronologis, mulai dari prapenelitian sampai pascapenelitian.Teknik analisis data berikutnya ialah analisis pada kesesuaian isi, kelayakanpenyajian, dan kebenaran bahasa, mengacu pada instrumen dari BSNP.

\section{HASIL PENELITIAN DAN PEMBAHASAN}

\section{A. Hasil Penelitian}

Berdasarkan indikator kelayakan isi BNSP dalam analisis buku teks Pendidikan Bahasa Indonesia SMP kelas VIII, telah ditemukan hasil analisis sebagai berikut :

Table 1 Hasil Analisis Kelayakan Isi Buku Ajar

\begin{tabular}{c|c|c}
\hline BAB & SKOR & PERSENTASE (\%) \\
\hline $\mathbf{1}$ & 32 & 72,7 \\
\hline $\mathbf{2}$ & 36 & 81,8 \\
\hline $\mathbf{3}$ & 37 & 84 \\
\hline $\mathbf{4}$ & 39 & 88,6 \\
\hline $\mathbf{5}$ & 40 & 90,9 \\
\hline $\mathbf{6}$ & 38 & 86,3 \\
\hline $\mathbf{7}$ & 38 & 86,3 \\
\hline $\mathbf{8}$ & 39 & 89 \\
\hline $\mathbf{9}$ & 39 & 89 \\
\hline Jumlah Rata-rata & 84,54 \\
\hline
\end{tabular}

Hasil analisis kelayakan isi pada buku ajar bahasaIndonesia kelas VIII kurikulum 2013 edisi revisi 2017 hanya bab 1 yang memperoleh kategori layak dikarenakan masih banyak materi, contoh, dan latihan yang tidak menyesuaikan dengan KI dan KD yang telah dirumuskan. Bab lainnya memperoleh kategori sangat layak karena sudah hampir sempurna menyajikan materi yang sesuai dengan KI dan KD yang harus dicapai. 
Berdasarkan indikator kelayakan isi BNSP dalam analisis buku teks Pendidikan Bahasa Indonesia SMP kelas VIII, telah ditemukan hasil analisis sebagai berikut :

Table 2 Hasil Analisis Kalayakan Bahasa Buku Ajar

\begin{tabular}{c|c|c}
\hline BAB & SKOR & PERSENTASE (\%) \\
\hline $\mathbf{1}$ & 20 & 83,3 \\
\hline $\mathbf{2}$ & 20 & 83,3 \\
\hline $\mathbf{3}$ & 22 & 91,6 \\
\hline $\mathbf{4}$ & 23 & 95,8 \\
\hline $\mathbf{5}$ & 20 & 83,3 \\
\hline $\mathbf{6}$ & 21 & 87,5 \\
\hline $\mathbf{7}$ & 20 & 83,3 \\
\hline $\mathbf{8}$ & 23 & 95,8 \\
\hline $\mathbf{9}$ & 22 & 91,6 \\
\hline Jumlah Rata-rata & 88,38 \\
\hline
\end{tabular}

Hasil analisis kelayakan bahasa pada buku ajar bahasaIndonesia kelas VIII kurikulum 2013 edisi revisi 2017 semua bab telah menggunakan bahasa yang sudah sesuai dengan tingkat intelektual siswa, sosioemosional siswa, tingkat keterbacaan, keterkaitan antarbab, dan keterkaitan antarparagraf.

\section{B. Pembahasan}

Dari analisis yang telah dipaparkan, diperoleh hasil sebagai berikut:

\section{Kelayakan Isi pada Buku Ajar Bahasa Indonesia SMP Kelas VIII} Edisi Revisi 2017 Penerbit Kementerian Pendidikan dan Kebudayaan

Persentase nilai kelayakan isi pada buku ajar Bahasa Indonesia SMP kelas VIII adalah $84,54 \%$ atau pada kategori sangat layak, dengan rincian sebagai berikut:

a. Kelengkapan Materi

Kelengkapan materi pada buku ini mendapat skor $86,11 \%$ atau pada kategori sangat layak. Hal tersebut dinilai dari beberapa bab yang sudah lengkap memuat KI dan KD pada setiap wacana, contoh, dan latihan seperti pada bab 2, 4, 6, dan 8 . 
Hanya beberapa bab yang kurang dalam memuat KI 1 pada buku ini seperti pada bab 1, 3, 5, 7 dan 9 yang dalam wacan, contoh, dan latihan tidak memuat KI 1 sama sekali.

\section{b. Kedalaman Materi}

Kedalaman materi pada buku ini mendapat skor 91,7\% atau pada kategori sangat layak. Hal tersebut dinilai dari beberapa bab yang sudah membahas konsep definisi, prinsip, prosedur, contoh, dan pelatihan yang dapat diterapkan sesuai dengan KI dan KD yang telah dirumuskan seperti pada bab 2, 4, 5, 6, 7, dan 8 sudah tersaji materi yang cukup dalam dan kesulitan dalam materi telah disesuaikan dengan tingkat perkembangan kognitif siswa. Ada beberapa bab yang tidak membahas pengertian dari teks yang dibahas seperti pada bab 1, 3, dan 9 sehingga skor pada kelengkapan materi pada ketiga bab tersebut adalah 3 .

c. Pemilihan Wacana, Teks, Gambar, dan Ilustrasi Sesuai dengan Kompetensi yang Harus Dicapai dan Bermanfaat Bagi Pemenuhan Rasa Ingin Tahu Peserta Didik

Pemilihan wacana, teks, gambar, dan ilustrasi sesuai dengan kompetensi yang harus dicapai dan bermanfaat bagi pemenuhan rasa ingin tahu peserta didik sudah sangat akurat dibahas dalam buku ini sehingga mendapat skor 100\%. Semua bab dalam buku ini sudah sangat akurat dalam menyajikan wacana, teks, gambar, dan ilustrasi yang sesuai dengan kompetensi yang harus dicapai dan bermanfaat bagi pemenuhan rasa ingin tahu peserta didik. wacana, teks, gambar, dan ilustrasi yang dengan kompetensi yang harus dicapai oleh siswa sangat baik untuk siswa karena siswa akan lebih mudah dalam memahami isi buku.

d. Konsep dan Teori Sesuai dengan Definisi yang Berlaku dalam Bidang Ilmu

Konsep dan teori sesuai dengan definisi yang berlaku dalam bidang ilmu dibahas secara akurat sehingga mendapatkan skor 100\%. Skor tersebut didapat dari 8 bab yang sudah memuat konsep dan teori yang sesuai dengan definisi Semua bab dalam buku ini sudah sangat akurat dalam menyajikan konsep dan teori yang sesuai dengan definisi yang berlaku dalam bidang ilmu dan tidak menimbulkan makna 
ganda yang akan membuat siswa menjadi bingung. Hal ini membuat siswa lebih mudah dalam memahami isi buku.

e. Pemilihan Contoh Sesuai dengan Kompetensi yang Harus Dicapai

Pemilihan contoh sesuai dengan kompetensi yang harus dicapai sudah sangat akurat dan medapatkan skor 91,7\%. Hal tersebut dinilai dari 8 bab yang telah menyajiakn secara akurat contoh yang sesuai dengan kompetensi yang harus dicapai Pada butir ini, dari 9 bab hanya 1 bab yang tidak menyajikan contoh yang sesuai dengan kompetensi yang harus dicapai siswa. Bab 1yang memperoleh skor 1 karena tidak menyajikan contoh yang sesuai dengan kompetensi yang harus dicapai siswa. Contoh-contoh pada bab 1 tidak mutakhir dan relevan dengan keadaan saat ini sehingga kurang akurat untuk mencapai kompetensi yang diharapkan.

f. Pelatihan, Penugasan, dan Penilaian Sesuai Tuntutan Penilaian Autentik

Pelatihan, penugasan, dan penilaian sesuai tuntutan penilaian autentik pada buku ini memperoleh skor $100 \%$ atau dalam kategori sangat akurat. Semua bab dalam buku ini sudah sangat akurat dalam menyajikan konsep dan teori yang sesuai dengan pelatihan, tugas, dan soal-soal yang diajukan dapat mengukur penguasaan pengetahuan, sikap, dan keterampilan peserta didik sesuai tuntutan penilaian autentik dan tidak ada soal yang dapat menimbulkan makna ganda yang akan membuat siswa menjadi bingung. Hal ini memudahkan siswa dalam mengembangkan dirinya.

g. Kesesuaian dengan Perkembangan Ilmu

Kesesuaian dengan perkembangan ilmu pada buku ini sudah diterapkan cukup baik sehingga memperoleh skor $94,44 \%$ atau dalam kategori sangat akurat. Hal tersebut dapat dilihat dari 7 bab yang memperoleh skor yang sempurna karena telah menyajikan setiap materi yang disajikan melalui wacana, teks, gambar, dan ilustrasi yang sesuai dengan perkembangan ilmu yang ada pada saat ini. Dua bab yang mendapat skor 3 dikarenakan masih memuat sebuah wacana atau contoh yang tidak sesuai dengan perkembangan ilmu yang ada pada saat ini. 


\section{h. Kesesuaian Fitur/Contoh/Latihan/Rujukan}

Kesesuaian fitur, contoh, latihan, dan rujukan pada buku ini sudah sesuai dengan memperoleh skor $88,9 \%$. Hal tersebut dikarenakan terdapat 7 bab yang telah menyajikan setiap contoh-contoh yang sesuai relevan dengan keadaan saat ini dan memiliki rujukan terbaru. Hanya terdapat dua bab yang memperoleh hasil buruk dalam buku ini dikarenakan dalam bab 1 dan 2 masih memuat contoh yang tidak relevan dengan kondisi yang ada saat ini.

i. Pengembangan Wawasan Kebhinekaan

Buku ini sangat kurang dalam menyajikan pengembangan wawasan kebhinekaan dalam wacana, contoh, dan latihan sehingga memperoleh skor 47,22\%. Hanya terdapat 2 bab yang menyajikan hal tersebut, yaitu pada bab 5 dan bab 1 yang memuat contoh-contoh yang menampilkan keberagaman daerah-daerah di Indonesia. Pada bab lainnya mendapat skor 1 karena tidak terdapat satu pun wacana, contoh, dan soal yang mampu mengembangkan wawasan kebhinekaan siswa.

\section{j. Pengembangan Wawasan Kebangsaan dan Integrasi Bangsa}

Buku ini juga tidak menyajikan wawasan kebangsaan dan integrasi bangsa pada wacana, contoh, dan latihan. Semua bab pada buku ini disajikan tanpa dapat mengembangkan wawasan kebangsaan dan integrasi bangsa yang dapat mengajak siswa untukmencintaibahasaIndonesia. Sehingga buku ini mendapatkan skor 30,6\% atau dalam kategori tidak layak.

k. Tidak Mengandung Unsur SARA, HAKI, Pornografi dan Bias (Gender, Wilayah, dsb)

Buku ini mendapat skor $100 \%$ karena tidak ditemukan materi yang disajikan melalui wacana, teks, gambar, dan ilustrasi yang mengandung unsur SARA, HAKI, pornografi, dan bias. Buku ini menyajikan materinya secara teliti tanpa memuat halhal yang negatif dan sensitif. Hal tersebut sangat baik dalam membangun moral siswa. 


\section{Kelayakan Bahasa pada Buku Ajar Bahasa Indonesia SMP Kelas}

VIII Edisi Revisi 2017 Penerbit Kementerian Pendidikan dan Kebudayaan

Persentase nilai kelayakan bahasa pada buku ajar Bahasa Indonesia SMP kelas VIII adalah $88,38 \%$ atau pada kategori sangat layak, dengan rincian sebagai berikut:

a. Kesesuaian dengan Tingkat Perkembangan Intelektual Peserta Didik

Kesesuaian bahasa dengan tingkat perkembangan intelektual peserta didik pada buku ini memperoleh skor 83,33\%. Nilai tersebut diberikan karena pada buku ini wacana, contoh, dan pelatihan mampu diabstraksi secara logis dan rasional oleh siswa dan setiap pelatihan yang bersifat hipotesis mampu diselesaikan.

b. Kesesuaian dengan Tingkat Perkembangan Sosial Emosional Peserta Didik

Kesesuaian bahasa dengan tingkat perkembangan sosial emosional peserta didik pada buku ini memperoleh skor yang sangat tinggi yaitu 94,44\%. Hal tersebut diperoleh karena pada buku ini menggunakan bahasa yang sesuai dengan tingkat perkembangan sosial emosional peserta didik pada wacana, contoh, dan pelatihan. Kesesuaian bahasa dengan tingkat perkembangan sosial emosional peserta didik dapat dilihat dari wacana, teks, gambar dan ilustrasi yang menggambarkan konsepkonsep mulai dari lingkungan terdekat (lokal) sampai dengan lingkungan global.

c. Keterbacaan Pesan

Keterbacaan pesan pada buku ini mendapat skor 69, 44\%. Pada butir ini, dari 9 bab hanya terdapat 1 bab yang memperoleh skor 1 atau dapat dikategorikan tidak sesuai. Bab 1 memiliki skor keterbacaan dibawah 3 yang artinya tingkat keterbacaannya sangat tinggi. Namun tingkat keterbacaan yang sangat tinggi tersebut tidak sesuai untuk siswa SMP. Tingkat keterbacaan yang tinggi tersebut lebih sesuai untuk siswa SD, karena wacana yang dibutuhkan siswa SMP adalah wacana yang mampu merangsang siswa untuk berpikir aktif dan menarik minat siswa untuk terus membaca buku pelajaran. Pada bab lainya sudah memperoleh skor 3 atau dalam kategori sesuai. 


\section{d. Ketepatan Bahasa}

Ketepatan bahasa pada buku ini memperoleh skor $86,11 \%$. Hal tersebut dapat dinilai dari pengguanaan bahasa yang sangat baik kerena sudah sesuai dengan pedoman umumejaanbahasaIndonesia. Hal yang membuat skor pada butir ini tidak cukup baik dikarenakan masih ada penggunaan bahasa yang kurang baku dan belum sesuai dengan pedoman umum ejaan bahasa Indonesia.

\section{e. Keruntutan dan Keterpaduan Bab}

Keruntutan dan keterpaduan bab pada buku ini memperoleh skor $100 \%$ atau dalam kategori sangat sesuai. Buku ini sudah sangat baik dalam penyampaian pesan antara satu bab dan bab lain yang berdekatan dan antar subbab dalam bab mencerminkan hubungan yang logis.

\section{f. Keruntutan dan Keterpaduan Paragraf}

Keruntutan dan keterpaduan paragraf pada buku ini memperoleh skor $100 \%$ atau dalam kategori sangat sesuai. Buku ini sudah sangat baik dalam penyampaian pesan antara satu paragraf dan paragraf lain yang berdekatan dan antarkalimat dalam paragraf mencerminkan hubungan yang logis.

\section{PENUTUP}

Buku ajar Bahasa Indonesia SMP kelas VIII edisi revisi 2017 penerbit Kementerian Pendidikan dan Kebudayaan dari segi kelayakan isi sudah dikategorikan pada kategori sangat layak dengan persentase $84,54 \%$. Isi pada buku tersebut sudah memuat materi yang sesuai dengan kompetensi yang harus dicapai siswa. Kedalaman pada buku juga sangat baik dan lengkap, telah mencakup sikap spiritual, sosial, pengetahuan, keterampilan pada setiap wacana dan contoh-contoh yang telah tersaji. Keakuratan materi pada buku ini sudah sangat akurat. Namun, pendukung materi pembelajaran pada buku ini masih terlalu sedikit menyajikan wacana, contoh, dan soal yang dapat mengembangkan wawasan kebhinekaan, wawasan kebangsaan, dan integritas bangsa yang mampu mengajak siswa untuk mencintai bahasa Indonesia sebagai identitas bangsa. 
Buku ajar Bahasa Indonesia SMP kelas VIII edisi revisi 2017 penerbit Kementerian Pendidikan dan Kebudayaan dari segi kelayakan bahasa sudah dikategorikan pada kategori sangat layak dengan persentase $88,38 \%$. Bahasa yang digunakan pada buku ini sudah disesuaikan dengan perkembangan intelektual dan sosial emosional siswa SMP. Bahasa pada buku ini juga komunikatif untuk siswa SMP karena keterbacaan pada setiap materi pada buku ini sudah bukup ideal untuk siswa SMP khususnya kelas VIII SMP dan hanya beberapa kesalahan kecil terkait ketepatan penggunaan bahasa Indonesia. Keruntutan dan keterpaduan bab, subbab, dan paragraf juga sudah sangat baik. Setiap subbab sudah memiliki hubungan yang logis antara satu subbab dan subbab yang lain begitu juga dengan keruntutan dan keterpaduan paragraf yang juga sangat baik. Saran yang dapat disampaikan yaitu 1)bagi guru agar lebih memerhatikan komposisi soal yang baik dan menambah soal keterampilan berpikir tingkat tinggi, 2) bagi siswa agar melatih kemampuan dengan mengerjakan soal-soal yang memuat keterampilan berpikir tingkat tinggi, 3) bagi peneliti lain agar mengembangkan penelitian ini seperti meneliti ranah afektif dan psikomotorik.

Dari hasil penelitian yang telah dilakukan, diharapkan dapat memberikan sedikit sumbangan berupa pemikiran yang digunakan sebagai usaha untuk meningkatkan kemampuan dalam bidang pendidikan.

\section{DAFTAR PUSTAKA}

Arikunto, S. 2010. Prosedur penelitian : Suatu Pendekatan Praktik. Jakarta: Rineka Cipta.

Badan Standar Nasional Indonesia. Instrumen Penilaian Buku Ajar. (http://bsnpindonesia.org/2014/05/28/instrumen-penilaian-buku-teks-pelajaran-tahun-

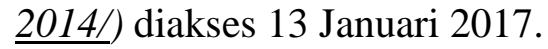

Muslich, Masnur. 2010. Text Book Writing: Dasar-dasar Pemahaman, Penulisan, dan Pemakaian Buku Teks. Jogjakarta: Ar-Ruzz Media.

Peraturan Pemerintah No. 19 Tahun 2005 tentang Standar Nasional Pendidikan.Jakarta: Depdiknas. 
Peraturan Pemerintah No. 32 Tahun 2013 tentang Standar Nasional Pendidikan. Jakarta: Depdiknas.

Peraturan Menteri Pendidikan Nasional Republik Indonesia No. 2 Tahun 2008 tentang buku.Jakarta: Depdiknas.

Sitepu, B.P. 2012. Penulisan Buku Teks Pelajaran. Bandung: Remaja Rosdakarya. 